\title{
Kalimat Metaforis Sebagai Sarana Estetika dalam Lirik Lagu nDangdut
}

\author{
M. Hermintoyo \\ Fakultas Ilmu Budaya Undip \\ Email: hermintpujangga@gmail.com
}

\begin{abstract}
Intisari
Dalam memberikan unsur estetikanya, penulis lirik akan mengekspresikannya lewat diksi puitis. Di tangan penulis lirik yang kreatif akan memunculkan bahasa figuratif. Pemahaman lirik yang metaforis tidak harus ada kesamaan arti yang ditulisnya. Bahasa puisi/ lirik yang puitis kata-katanya bias maknanya tergantung dari pemahaman penyimaknya.Begitu pun dalam lirik lagu nDangdut. Pada umumnya lirik lagu nDangdut cenderung bertemakan cinta dibandingkan tema-tema yang lain. Artikel ini membicarakan diksi metaforis sebagai sarana estetika. Pemaknaan diksi metaforis menggunakan bacaan hermeunetik.
\end{abstract}

Kata kunci: diksi, metaforis, hermeunetik, lirik, dangdut

\begin{abstract}
Abstract In providing an aesthetic element, the lyricist will express it through poetic diction. In the hands of creative lyric writers, a figurative language will emerge. Metaphorical lyrics understanding does not have to have the same meaning that is written. Poetic language / poetic lyrics, the words can mean the meaning depends on the listener's understanding. Even so in the song nDangdut. In general, the song Dangdut tends to have a theme of love compared to other themes. This article discusses metaphorical diction as an aesthetic means. Meaning of metaphorical diction using hermeneutical reading.
\end{abstract} Keywords: diction, metaphor, hermeunetic, lyrics, dangdut

\section{PENDAHULUAN}

Alat untuk menyampaikan perasaan dan pikiran pengarang adalah bahasa. Baik tidaknya bergantung pada kecakapan pengarang dalam menggunakan kata-kata. Pengarang dalam mencurahkan perasaan dan isi pikiran yang setepat-tepatnya haruslah memilih kata yang pas dan dapat menimbulkan imajinasi estetik yang hasilnya disebut diksi puitis (Pradopo 1987:54).

Untuk mendapatkan kepuitisan, pengarang dapat menggunakan bahasa kiasan (figurative language). Dengan bahasa kiasan ini lirik menjadi semakin hidup yang dapat memberikan ciri puitis. Kiasan ini berupa kalimat metaforis. Wahab (1995:42) menyebutkan metafora adalah ungkapan kebahasaan yang maksudnya tidak dapat dijangkau secara langsung dari lambang yang dipakai karena makna yang dimaksud terdapat pada prediksi ungkapan kebahasaan itu. Dengan kata lain, metafora adalah pemahaman dan pengalaman akan sejenis hal yang dimaksud untuk perihal lain. 
Estetika puisi tidak hanya tergantung pada keluasaan ide yang dituangkan oleh penyair dalam karya-karyanya melalui kesatuan kata dan kalimat yang membentuk larik dan bait, tetapi juga bersentuhan dengan bunyi. Jassin (1983:40) menjelaskan bahwa dalam puisi, pikiran dan perasaan sering bersayap, ditambah lagi dengan syarat keindahan bahasa, tekanan suara, bunyi, dan lagu.

Unsur puisi dibina terutama dalam kemerduan bunyi (Ensten, 1984:10). Unsur penting puisi adalah bunyi sebab keindahan puisi dilihat orang sebagai keindahan bunyi (Junus, 1983:131). Bunyi merupakan unsur estetika puisi sebagai tenaga ekspresif. Tenaga ekspresif dalam pengertian ini berarti bahwa bunyi mempunyai tugas untuk memperdalam ucapan, memperkuat nilai rasa, menegaskan suasana, menumbuhkan bayangan anganangan, dan sebagainya (Pradopo, 1987:22). Slametmuljana (1956:57) mengatakan bahwa bunyi dalam puisi merupakan realitas simbolik. Setiap kata menimbulkan asosiasi dan menciptakan tanggapan di luar arti yang sebenarnya. Hal itu berarti bahwa bunyi yang diungkapkan dengan memanfaatkan gaya bahasa dapat mengarahkan dan memberikan efek perasaan tertentu terhadap puisi.

Demikian juga lirik lagu dalam memberikan aspek estetika diperlukan seperti puisi. Diksi dipilih untuk menguatkan gagasan dengan bahasa majas atau kata-kata metaforis. Diksi metaforis secara kreatif dapat dibedakan yang berupa simbol umum (blank symbol) dan ) simbol khusus (private symbol). Aminuddin ( 2000a:140-142) menjelaskan Blank symbol jika kata yang diungkapkan acuan maknanya bersifat universal sehingga pembaca mudah menafsirkan. Private symbol jika kata-kata yang diciptakan mengungkapkan simbol secara khusus, dan digunakan pengarang untuk mengungkapkan keunikan atau gaya ciptaannya. Begitu pun dengan lirik lagu nDangdut, di tangan pengarang/ penulis lirik lagu yang kreatif akan memberikan sajian diksi yang estetis.

Lirik lagu (nDangdut) adalah ekspresi personal, artinya lirik itu luapan perasaan atau sebagai produk imajinasi pengarangnya. Dengan demikian, aspek emosional sangat mendominasi. Dapat dikatakan lirik lagu adalah bahasa perasaan yang membawa perasaan pribadi pengarangnya. Semua itu tercermin dalam pilihan kata yang dipakai berdasarkan simbol-simbol yang digunakan. Lirik lagu dibuat dengan pilihan kata dan susunan yang baik, ada koherensi internal. Dengan demikian, fungsi bahasa yang menonjol adalah bersifat puitik, yakni fungsi untuk menggambarkan makna seperti yang terdapat dalam lambang/ simbol kebahasaan itu sendiri. 
Sebagai refleksi realitas menunjukkan puisi (lirik lagu) itu berhubungan dengan kenyatan. Puisi adalah imitasi, refleksi, atau reopresentasi dunia dan kehidupan manusia yang bersifat referensial, yaitu fungsi yang menggambarkan objek, peristiwa, benda, pandangan, atau sikap yang akan di sampaikan lewat imajinya. Lirik lagu nDangdut temanya bervariatif sesuai dengan refleksi realitas bisa percintaan, kelaparan, kesedihan dsb. Seperti halnya lirik-lirik genre lagu tertentu pada umumnya bertemakan tentang percintaan. Demikian juga dengan tema-tema lirik lagu nDangdut kecenderungannya bertema percintaan. Tema-tema semacam ini sifatnya universal.

\title{
METODE PENELITIAN
}

Data berupa lirik lagu nDangdut yang diperoleh melalui CD yang dijual di pasaran juga dicari di media internet. Data diambil secara purposive sampling dicari sesuai kebutuhan yang ada kalimat metaforisnya.

Metode yang digunakan adalah metode pustaka dengan teknik simak catat. Langkah-langkah yang dilakukan: Setelah data diperoleh kemudian didengarkan berulangulang, dicatat dan diklasifikasi sesuai tujuan penelitian.

Analisis data menggunakan metode struktural, yaitu melihat unsur intrinsiknya, khususnya pilihan kata/ diksinya yang bermajas (bermetaforis). Untuk mendapatkan makna yang terkandung di diksinya diperlukan pembacaan hermeunetik yaitu memparafrasakan kata-kata metaforisnya. Untuk memahami makna puisi atau lirik diperlukan kode bahasa, sastra dan budaya (Hermintoyo, 2017).

\section{HASIL PENELITIAN}

\section{Data 1. "Cinta Berawan" Rita Sugiarto}

\author{
Jauh sudah langkah cinta kita berdua \\ walau disadari tertutup awan gelap \\ bertambah ia bertambah \\ bertambah hitam dan gelap awan yang menutupinya \\ sampai detik ini gelap masih membayang \\ bilakah berlalu langit kembali cerah \\ berakhir segalanya \\ berakhir awan hitam yang menutup cinta kita berdua
}


Bait pertama lirik lagu ini menggunakan kata-kata metaforis / jauh sudahlangkah cinta/ yang menggambarkan percintaannya serius, tetapi tidak jelas /tertuup awan gelap/. Disadari hal itu terjadi sejak dulu sampai sekarang (sampai detik ini gelap masih membayang/. Diharapkan cintanya yang tidak jelas/ pasti itu berakhir dengan kepastian tanpa kendala /bilakah berlalu langit kembali cerah...berakhir awan hitam yang menutup cinta.../.

Lelah... lelah ku menanti bersinarnya rona pelangi lama... lama kumenunggu hari hari gelap membisu dimanakah kau pelangi kau datanglah menyinari jangan biarkan gelap terus melanda

Pada bait kedua, digambarkan keinginan si aku lirik yang kelelahan menanti yang diharapkan adalah adanya keindahan /rona pelangi/ bukan kesepian /gelap membisu/.

Betapa besarnya pengorbanan dirimu dalam penantian saat cinta berawan menanti segalanya menanti awan hitam yang menutup cinta kita berdua

Pada bait ketiga, si aku lirik merasa bangga terhadap pacarnya yang mau menanti berkorban sampai percintaan mereka jelas lepas dari persoalan yang dihadapi. Lirik dengan judul "Cinta Berawan" dapat disimpulkan perjalanan cinta mereka yang mendapat rintangan mungkin dari keluarga dan seterusnya, tetapi tetap mempertahankan karena punya harapan. Semuanya terselesaikan dan jelas /menanti awan hitam yang menutup cinta kita berdual.

\section{Data 2. "Senyum Membawa Luka" Meggy Z}

Anggur merah yang slalu memabukkan diriku kuanggap

Belum seberapa Dahsyatnya

Bila dibandingkan dengan senyumanmu membuat aku Jatuh bangun

Anggur merah yang slalu memabukkan diriku kuanggap

Belum seberapa Dahsyatnya

Bila dibandingkan dengan rayuanmu membuat aku

Lesu darah 
Bait satu maupun dua menggambarkan seseorang sedang jatuh cinta yang dimeforkan bagai orang mabuk /anggur merah/ belum seberapa dibandingkan dengan mabuk kepayangnya jatuh cinta yang luar biasa /senyuman membuat jatuh bangun/, dan/ rayuanmu membuat aku lesu darah//

Untuk apa kau berikan aku benang yang kusut Sementara diriku harus membuat kain kain yang halus Untuk apa kau hidangkan aku cinta yang kalut Sementara tanganmu telah engkau berikan pada yang lain Sungguh teganya dirimu teganya teganya teganya teganya Oh pada diriku

Pada bait ketiga digambarkan cintanya rumit dan tidak jelas /benang kusut/ sementara si aku lirik harus memberikan keindahan dan tulus /kain yang halus/ . Kata kusut dan kalut mempertegas cintanya tidak menyenangkan.. Ketulusan cintanya ternyata tidak kesampaian karena kekasih yang diharapkan lebih memilih orang lain / sementara tanganmu telah berikan pada orang lain/.

\author{
Aku masih belum mau mati karena cintamu \\ Lalu menderita \\ Walaupun tali cinta masih mengikat-ikat di leherku \\ Lebih baik ku kecewa daripada ku merana \\ Hingga terluka \\ Karna pengobat cinta sungguh sangat mahal-mahal harganya \\ Laksana menabur uang tapi hati ini sakit sendiri \\ Laksana ketiban bulan tapi bumi ini hancur sendiri
}

Pada bait terakhir digambarkan si aku lirik mempunyai sikap tidak akan putus asa / aku belum mau mati karena cintamu...lalu menderita/ meskipun diakui cintanya sangat kuat / cinta masih mengikat di leherku/. Sakit cinta sangat mahal mengobatinya/pengobat cinta sangat mahal harganya/. Diibaratkan memiliki segalanya tetapi tidak ada gunanya atau berakibat terbalik menghancurkan diri sendiri / laksana menabur uang tapi hati sakit sediri, laksana ketiban bulan tapi bumi ini hancur sendiri/. 


\section{Data 3. "Cinta Sampai di sini” Mansyur S}

Barulah sekarang aku menyadari

Cintamu padaku oh sekulit ari

Tiada kusangka engkau

Sampai hati nodai cintaku yang suci mulia

Panas bara api membakar tubuhku

Lebih panas lagi oh terbakar hati

Telah kucoba hati tak mau lagi

Lebih baik cinta oh sampai disini

Lirik lagu data 3 terdiri dari dua bait. Bait pertama menceritakan si aku lirik yang menyadari bahwa pacarnya cintanya tipis setipis kulit ari. Ketakterdugaannya cintanya yang sungguh-sungguh ternyata disilingkuhi / tiada kusangka engkau sampai hati nodai cintaku yang suci mulial.

Di bait kedua si aku lirik merasa sakit hati yang luar biasa dimetaforkan seperti Ipanas bara api membakar tubuhku, lebih panas lagiterbakar hati/.Si aku lirik mencoba menghindar dari rasa sakit hati karena cinta. Akhirnya memutuskan untuk tidak melanjutkan percintaannya / lebih baik cinta sampai di sini/.

\section{Data 4. "Bulan Di Ranting Cemara" Elvi Sukaesih}

(Bulan di ranting cemara

Menambah kerinduan)

Lepas senja remang melingkar langit

Tak terasa rindu mulai bangkit

Janji alam di malam ini

Rembulan kan datang menyinari

Cipta alam kadang membawa suka

Ada bulan di ranting cemara

Rindu rindu makin menderu

Ku ingin kau ada di sisiku

Bait pertama dilukiskan suasana senja yang masuk kemalam / lepas senja remang melingkar langit/ mulailah ada rindu / tak terasa rindu mulaai bangkit/. Seperti biasa jika malam pasti muncul bulan dengan sinarnya dan menyenangkan /cipta alam membawa suka /. Ada kerinduan lembut lada bulan di ranting cemara. Rindu makin menderu/.Kehadiran seseorang sangat dibutuhkan / kuingin kau ada di sisiku/.. 
Esok hari setelah engkau kembali

Ku kan datang menemuimu

Bercerita betapa rindu hatiku

Malam itu ku hanya sendiri

Bisik ranting cemara

Bulan bersinar manja

Rindu hatiku semakin dalam

Bait berikutnya dijelaskan esok hari si aku lirik akan datang menemui dan akan bercerita tentang kerinduannya dalam kesendirian tetapi rindu itu indah seperti suara gesekan ranting cemara bunyinya lembut disinari rembulan / bisik ranting cemara, bulan bersinar manjal. Rindu semakin mendalam

Rumpun bambu di sisi kau cemara

Menambah indahnya suasana

Angin malam berbisik merdu

Melintas burung malam berlalu

Cipta alam kadang membawa suka

Ada bulan di ranting cemara

Rindu rindu makin membara

Tersenyum bulan di ranting cemara

Bait terakhir digambarkan suasana alam dengan pohon bambu dan cemara . Angin malam mulai terasa / angin malam berbisik merdu/. Burung malam berlalu menandakan akan ada pergantian dari malam ke pagi. Alam begitu indah. Ada perasaan senang apalagi jika melihat bulan di antara sela ranting cemara yang lembut. Rindu itu semakin kuat.

\section{Data 5. "Janur Kuning" Nur Halimah}

Jangan kau katakan dulu

Jangan kau siarkan dulu

Sebelum janur kuning

Hiasan cinta melambai-lambai

Di depan rumahku ini

Kalau sudah saatnya

Sumpah perkawinan kita

Semua menjadi milikmu

Bait pertama data 6 menggunakan diksi metaforis "janur kuning" kode budaya di suku Jawa yang menggambarkan sahnya perkawinan. Janur kuning biasanya dipakai sebagai hajatan pernikahan. Dalam lirik tersebut menggambarkan seseorang yang menginginkan agar pacarnya tidak menganggap milikny kalau belum disahkan dalam 
pernikahan dengan sumpah yang diucapkan ketika akad nikah sebagai tanda cintanya sempurna dalam undang-undang perkawinan dan kaidah agama //sebelum janur kuning/ hiasan cinta melambai-lambaidi depan rumah kita //, //Kalau sudah saatnya sumpah perkawinan kita/ semua menjadi milikmu//.

Dari bukit-bukitnya yang menghijau

Sampai lautan yang biru

Kakanda sayang aduh-aduh

Kakanda sayang

Kakanda sayang aduh-aduh

Kakanda sayang

Aku pun mengharap

Belaian tanganmu sayang

Tetapi ku tahan ku tahan

Karena malu dilihat orang

Walaupun ku tahu

Engkau yang paling ku sayang

Rasanya ku ingin ku ingin

Masuk ke dalam pintu hatimu

Ibarat bulan sudah di tangan

Ibarat bintang sudah bertaburan

Cinta suci kita

Kini menjadi kenyataan

Pada bait berikutnya mempertegas bahwa cintanya yang subur (hijau) dan dalam (lautan yang biru) dengan lirik metafor // dari bukit-bukit yang menghijau/ sampai lautan yang biru//. Ingin rasanya bercinta //aku mengharap belaian cinta//, tetapi ditahan. Tidak dipungkiri ada hasrat yang luar biasa //Rasanya kuingin kuingin/ masuk ke pintu hatimu//.

Pada bait terakhir semua sudah bisa dipastikan dengan mengibaratkan //bulan sudah di tangan/ bintang sudah bertaburan/ cinta suci kita kini menjadi kenyataan//. Keindahan kebahagiaan, cita-cita cintanya terpenuhi karena adanya cinta sucinya.

\section{Data 6. “ Bumi Pun Turut Menangis"Rita Sugiarto}

Kering sudah air mataku, 
Menangis di dalam sepi..

Namun kau tak mau mengerti,

Dan selalu menyakiti..

Walaupun diriku selalu mengalah,

Dan menuruti kehendakmu..

Sampai kapan aku bertahan..

Data 6. Pada bait pertama menggambarkan si aku lirik mengalami penderitaan dalam bercinta meskipun selalu mengalah //kering sudah air mataku/menangis di dalam sepi..../selalu menyakiti/ walaupun diriku selalu mengalah//. Ada pernyataan si aku lirik penderitaan itu akan berhenti //sampai kapan aku bertahan//.

Bila kau marah padaku,

Bumipun turut menangis..

Karena bukan hanya mulutmu,

Tanganmu pun turut bicara..

Kau dera diriku kau cambuk diriku,

Bagai hewan tak berdaya..

Pada bait kedua digambarkan si aku lirik mengalami kekasaran dari caci maki dan kekerasan fisik, seperti bukan manusia tetapi layaknya hewan. Perlakuan itu dipertegas secara bombastis dengan dinyatakan seperti // bumi pun turut menangis//.

Kini hidup kita berdua,

Bagai rembulan dan mentari..

Walau sama menerangi bumi,

Namun tak mungkin dapat bersatu..

Walaupun serumah itu karena dia,

Buah hati perkawinan kita.

Mengapa ini harus terjadi..

Pada bait terakhir, si aku lirik terpaksa hidup berumah tangga, tetapi sebenarnya tidak ada kecocokan //bagai rembulan dan mentari/ walau sama menerangi bumi/ namun tak mungkin bersatu/l. Semua itu dijalani karena adanya anak //buah hati perkawinan kita/l. 


\section{SIMPULAN}

Dalam memberikan unsur estetikanya, penulis lirik akan mengekspresikannya lewat diksi puitis. Di tangan penulis lirik yang kreatif akan memunculkan bahasa figuratif. Pemahaman lirik yang metaforis tidak harus ada kesamaan arti yang ditulisnya. Bahasa puisi/ lirik yang puitis kata-katanya bias maknanya tergantung dari pemahaman penyimaknya. Begitu pun dalam lirik lagu nDangdut. Pada umumnya lirik lagu nDangdut cenderung bertemakan cinta dibandingkan tema-tema yang lain. Cinta yang banyak dibicarakan cenderung tentang kegagalan cinta, sakit hati yang berlebihan.

\section{DAFTAR PUSTAKA}

Aminuddin.2000. Pengantar Apresiasi Karya Sastra. Bandung: Sinar Baru.

Esten, Mursal (ed.) 1988. Menjelang Teori dan Kritik Susastra IndonesiaYang Relevan. Bandung: Angkasa.

Hermintoyo, M. 2017. Kode Bahasa dan Sastra. Semarang: Gigih Pustaka.

Imron, D. Zamawi.2002. Citra Lingkungan Hidup dan Kehati dalam Puisi-Puisi Indonesia Modern. Yogyakarta: Adicita Karya Nusa.

Jassin, H.B. 1983. Tifa Penyair dan Daerahnya. Jakarta: Gunung Agung.

Junus, Umar.1983. Dari Peristiwa ke Imajinasi: Wajah Sastra dan BudayaIndonesia. Jakarta: Gramedia.

Pradopo, Rahmat Djoko. 1987. Pengkajian Puisi. Yogya: Gajah Mada University Press.

Preminger, Alex.2001. "Semiotik (Semiologi)". Terjemahan Rahmat Djoko Pradopo dalam Metodologi Penelitian Sastra. (Ed.) Jabrohim. Yogyakarta: Hanindita.

Slametmuldjono dan B. Simorangkir Simanjuntak. 1956. Ragam Bahasa Indonesia. Jakarta: J.B. Walters.

Wahab, Abdul.1995. Isu Linguistik. Surabaya: Airlangga University Press.

Waluyo, Herman J. 1987. Teori dan Apresiasi Puisi.Jakarta: Erlangga. 